\title{
HAK ASUS ANAK : SUATU ANALISA TERHADAP PUTUSAN MAHKAMAH SYAR'IYAH LANGSA TENTANG PENGALIHAN HAK ASUH ANAK
}

Oleh : Fakhrurrazi ${ }^{1}$ dan Noufa Istianah ${ }^{2}$

\begin{abstract}
Abstrak
Dalam pembahasan ini peneliti memfokuskan kepada pemeliharaan anak akibat keadaan suami istri dalam suatu keluarga yang terjadi perselisihan dan pertengkaran yang sangat memuncak, dan tidak dapat didamaikan lagi, yang berakhir dengan perceraian. Akibat perceraian, terjadilah perselisihan mengenai pemeliharaan anak. Suami menghendaki hak asuh diberikan kepadanya, demikian pula sang mantan istri nya. Meskipun dalam agama menetapkan bahwa wanitalah yang paling berhak untuk mengasuh anak yang belum mumayyiz, tetapi di dalam keadaan ibunya belum menikah lagi.
\end{abstract}

Kata Kunci : Pemeliharaan Anak, Hak Asuh Anak

\section{A. Pendahuluan}

Pokok masalah yang menjadi rumusan masalah dalam penelitian ini adalah bagaimana pemeliharaan hak asuh anak menurut Hukum Islam dan UndangUndang, serta bagaimana metode yang digunakan Hakim dalam mengambil keputusan tentang pemeliharaan hak asuh anak di Mahkamah Syar'iyah Langsa. Penelitian ini bertujuan untuk mengetahui bagaimana pemeliharaan hak asuh anak di dalam hukum Islam dan Undang-undang dan metode apa yang digunakan hakim dalam memutus perkara tersebut. Penelitian ini menggunakan metodologi kualitatif dengan pendekatan yuridis-normatif. Adapun teknik pengumpulan data mengunakan metode dokumentasi dan wawancara. Hasil penelitian menunjukkan bahwa; (1) Pemeliharaan hak asuh anak menurut Hukum Islam yaitu melakukan pemeliharaan anak yang masih kecil (belum tamyiz), baik laki-laki maupun perempuan, dengan menyediakan sesuatu yang menjadi kebaikannya dan menjaganya dari sesuatu yang menyakiti dan merusaknya. Adapun pemeliharaan hak asuh anak dalam Undang-Undang dijelaskan dalam pasal 42 dan 45. (2)

\footnotetext{
${ }^{1}$ Penulis adalah kepala LBH IAIN Langsa dan Dosen pada Fakultas Syariah IAIN Langsa

2 Penulis adalah mahasiswa pada fakutas syariah IAIN Langsa
} 
Metode yang digunakan Hakim dalam mengambil keputusan tentang pemeliharaan hak asuh anak di Mahkamah Syar'iyah dalam Putusan Perkara No.150/Pdt.G/2015/ adalah dengan menggunakan metode yuridis undang-undang mengamanahkan anak yang masih di bawah umur berada di pengasuhan ibunya, walaupun ibunya sudah menikah lagi, namun jika terdapat hal-hal buruk yang dapat dikatagorikan bisa mempengaruhi hak pengasuhan anak maka itu bisa dikesampingkan dan berdasarkan ketentuan tersebut hak pengasuhan bisa dialihkan.

Pemeliharaan anak merupakan hak bagi anak-anak yang masih kecil, karena ia membutuhkan pengawasan, penjagaan, pelaksanaan segala urusan dan orang yang mendidiknya. Ibulah yang berkewajiban melakukan Pemeliharaan anak (hadhanah).

Hadhanah adalah salah satu bentuk dari kekuasaan dan kepemimpinan. Namun demikian, dalam hal ini perempuan lebih layak untuk menempatinya karena kaum hawa bisa lebih lembut, penuh kasih sayang, dan sabar dalam mendidik. Jika si anak sudah mencapai usia tertentu maka hak pemeliharaannya dilimpahkan kepada lelaki, karena ia lebih mampu menjaga dan mendidik si anak dari pada kaum wanita. ${ }^{3}$

Bila anak telah melewati masa kanak-kanak yaitu mencapai usia tujuh tahun, yang dikatakan sebagai mumayyiz, dan tidak idiot, antara ayah dan ibu berselisih dalam memperebutkan hak Pemeliharaan anak, maka si anak diberi hak pilih antara tinggal bersama ayah atau ibu untuk pengasuhan selanjutnya. ${ }^{4}$

Pemeliharaan anak (Hadhanah) dapat ditangani orang lain, seperti bibi perempuan dan ia rela melakukan tugas tersebut, sedangkan ibunya tidak mau, maka hak ibu untuk mengasuh menjadi gugur dengan sebab bibi perempuan yang mengasuhnya pun mempunyai hak hadhanah ( Pemeliharaan anak ). ${ }^{5}$

Pemeliharaan anak (Hadhanah) hukumnya wajib karena anak yang tidak dipelihara akan terancam keselamatannya, sebagaimana juga wajib memberi

\footnotetext{
${ }^{3}$ Wahbah Az-Zuhaili, Fiqih Islam Wa Adillatuhu, jilid 10, Terj. Abdul Hayyie al-Kattani dkk., (Jakarta: Gema Insani \& Darul Fikir, 2011), hlm. 60.

${ }^{4}$ Amir Syarifuddin, Hukum Perkawinan Islam di Indonesia: Antara Fiqh Munakahat dan Undang-Undang Perkawinan, (Jakarta: Kencana, 2007), hlm. 330.

5 Slamet Abidin, Fiqh Munakahat, (Bandung : Pustaka Setia, 1999 ), hlm. 171-172.
} 
nafkah kepada anak. ${ }^{6}$ Seorang anak pada permulaan hidupnya sampai pada umur tertentu, memerlukan orang lain untuk membantu dalam kehidupannya, seperti makan, pakaian, membersihkan diri, bahkan sampai kepada pengaturan bangun dan tidur. Oleh karena itu, orang yang menjaganya perlu mempunyai rasa kasih sayang, kesabaran, dan mempunyai keinginan agar anak itu baik (saleh) di kemudian hari. Di samping itu dia harus mempunyai waktu yang cukup pula untuk melakukan tugas itu. Dan orang yang memiliki syarat-syarat tersebut adalah wanita. Oleh karena itu, agama menetapkan bahwa wanita adalah orang yang sesuai dengan syarat-syarat tersebut. Proses pemeliharaan anak dan pendidikannya akan dapat berjalan dengan baik, jika kedua orang tua saling berkerja sama dan saling membantu. Tentu saja ini dapat dilakukan dengan baik jika keluarga tersebut benar-benar keluarga yang rukun.

Dalam pembahasan ini peneliti memfokuskan pada pemeliharaan anak akibat keadaan suami istri dalam suatu keluarga yang terjadi perselisihan dan pertengkaran yang memuncak, dan tidak dapat didamaikan lagi, yang berakhir dengan perceraian. Akibat perceraian, terjadilah perselisihan mengenai pemeliharaan anak. Suami menghendaki hak asuh diberikan kepadanya, demikian pula sang mantan istrinya. Meskipun dalam agama menetapkan bahwa wanitalah yang paling berhak untuk mengasuh anak yang belum mumayyiz, tetapi di dalam keadaan ibunya belum menikah lagi, maka ibu diutamakan untuk mengasuhnya, sebab dia lebih mengetahui dan lebih mampu mendidik anak. Juga karena ibu mempunyai rasa kesabaran untuk melakukan tugas ini yang tidak dimiliki oleh bapaknya. Ibu juga lebih mempunyai waktu untuk mengasuh anaknya dari pada bapak. Oleh karena itu peran ibu sangat penting dalam mengatur kemaslahatan anak. Dan bagaimana jika ayahnya pernah menyalah gunakan narkoba, bagaimana jika anak tersebut diasuh oleh ayah, tentu jika ayah yang mengasuh maka itu akan mengganggu psikologis anak tersebut. Dan tidak dapat menjamin keselamatan/kesehatan jasmani dan rohani anak karena sering ditinggal ayah serta dengan tabiat buruk yang menjadi contoh tidak baik bagi perkembangan moral anak.

${ }^{6}$ Tihami dan Sohari Sahrani, Fikih Munakahat: Kajian Fikih Nikah Lengkap, (Jakarta: Rajagrafindo Persada), hlm. 216. 
Keutamaan hak ibu itu ditentukan jika dia belum kawin dan dia memenuhi syarat untuk melaksanakan tugas hadhanah. Bila kedua atau salah satu dari syarat ini tidak terpenuhi, umpamanya dia telah kawin atau tidak memenuhi persyaratan maka ibu tidak lebih utama dari ayah. Bila syarat itu tidak terpenuhi maka hak pengasuhan pindah kepada yang paling dekat yaitu ayah. Bila ayah tidak ada maka yang berhak mendidik adalah bibi (saudara perempuan ibunya).

Pemeliharaan dan pendidikan anak pada dasarnya adalah kewajiban kedua orang tua sebagaimana diatur dalam Pasal 41 huruf (a) Undang-Undang Nomor 1 Tahun 1974 "Bahwa kewajiban pemeliharaan dan pendidikan anak adalah tanggung jawab kedua orang tua, kewajiban mana berlaku terus meskipun perkawinan kedua orang tua putus", dari ketentuan di atas dapat dipahami bahwa perceraian tidak memutus hubungan anak dengan kedua orang tua, penetapan pemeliharaan anak hanyalah semata-mata untuk kepentingan anak sehingga tidak menjadi korban akibat perceraian kedua orang tuanya.

Berdasarkan ketentuan tersebut di atas, disimpulkan bahwa pengadilan berhak memberikan keputusan bila terjadi perselisihan mengenai penguasaan anak. Selain itu, Kompilasi Hukum Islam (KHI) Pasal 98 tentang pemeliharaan anak, disebutkan bahwa "Batas usia anak yang mampu berdiri sendiri atau dewasa 21 tahun, sepanjang tidak cacat fisik atau mental”.

Hadhanah sebagai salah satu akibat putusnya perkawinan diatur secara panjang lebar oleh KHI dan materinya hampir keseluruhan mengambil dari fiqh menurut jumhur ulama, khususnya syafi' ${ }^{1}$ yah. ${ }^{7}$

Jika seorang ibu menikah dengan laki-laki lain maka hak hadhanah tidak dapat diberikan kepadanya sesuai dengan syarat-syarat hadhanah, bila hal tersebut terjadi maka yang mengambil hak hadhanah adalah ayahnya, akan tetapi bagaimana jika seorang ayah pernah menyalahgunakan narkoba. Menimbang bahwa prilaku tersebut dapat memberikan dampak psikologis yang buruk kepada

\footnotetext{
${ }^{7}$ Amir Syarifuddin, Hukum Perkawinan..., hlm. 334-335.
} 
anak dan dapat merusak diri serta masyarakat sebagaimana disebutkan dalam Pasal 24 ayat 2 Undang-Undang Nomor 35 tahun 2009 tentang narkoba. ${ }^{8}$

Ada beberapa faktor penyebab hak hadhanah jatuh kepada ibu walaupun ibu sudah menikah lagi dengan laki-laki lain, beberapa hal inilah yang dapat membuat sang ayah tidak dapat hak pemeliharaan (hadhanah) terhadap anak yaitu:

1. Tidak beragama Islam/pindah dari agama Islam (Murtad)

2. Berkelakuan buruk, seperti pemabuk, penjudi, pencandu narkoba/pernah menyalah gunakan narkoba, penganiayaan.

3. Mengalami gangguan jiwa. ${ }^{9}$

Disamping itu, hakim juga tidak hanya mempertimbangkan berhak atau tidak seorang ayah untuk mengasuh anaknya, akan tetapi hakim juga mempertimbangkan apakah ibunya mampu memelihara anak tersebut. Ibu dari anak tersebut harus sanggup dan bertanggung jawab atas pemeliharaan, pendidikan dan biaya hidup anak.

Dalam kasus tertentu pertimbangan hakim dalam mengambil suatu hukum didasarkan pada kitab-kitab klasik dan hukum materil seperti Kompilasi Hukum Islam sehingga hakim memberikan hak hadhanah kepada ibunya dengan alasan bahwa sang ayah akan berpindah tempat. ${ }^{10}$

Kompilasi Hukum Islam sebagai hukum materil bagi lingkungan Pengadilan Agama maupun Undang-Undang Nomor 50 Tahun 2009 tentang perubahan kedua atas Undang-Undang Nomor 7 Tahun 1989 tentang Peradian Agama belum memberikan jawaban secara limitative terhadap beberapa permasalahan hukum dalam menetapkan pengasuhan anak ketika kedua orang tuanya bercerai.

Ketentuan hukum yang tertera pada Undang-Undang Nomor 39 Tahun 1999 tentang Hak Asasi Manusia Pasal 51 ayat (2) dimana setelah putusnya perkawinan, seorang wanita mempunyai hak dan tanggung jawab yang sama

\footnotetext{
8 Zulkarnain Nasution, Ahmad Dayan Lubis, dll, Kompilasi Peraturan PerundangUndangan tentang Narkoba, (Pimansu), hlm. 91.

${ }^{9}$ Abdul Fatah Idris, Abu Ahmadi, Fiqih Islam Lengkap, (Jakarta: PT Rineka Cipta, 2004) h. 291 .

${ }^{10}$ Amir Syarifuddin, Hukum Perkawinan..., h. 327-328.
} 
dengan mantan suaminya atas semua hal yang berkenaan dengan anak-anaknya. Disamping itu ketentuan yang terdapat pada pasal 49 Undang-Undang Nomor 1 Tahun 1974 tentang Perkawinan menerangkan tentang adanya kemungkinaan orang tua (ayah/ibu) atau salah satunya dicabut kekuasaannya untuk waktu tertentu dengan alasan ia sangat melalaikan kewajiban terhadap anaknya atau ia berkelakuan buruk atau sebagai pengguna narkoba. Hal ini menunjukkan bahwa penetapan pengasuhan anak terhadap salah satu dari kedua orang tua bukan merupakan penetapan yang bersifat permanen, akan tetapi sewaktu-waktu hak pengasuhan anak dapat dialihkan melalui pengajuan gugatan pencabutan kekuasaaan ke pengadilan.

Mengenai hal ini, dapat dikaji melalui kasus perkara No. 0150/Pdt.G/2015/ Makamah Syar'iyah Langsa yaitu yang dalam duduk perkaranya mengenai hak pengasuhan anak (hadhanah) pasca perceraian dan ayah yang pengguna narkoba.

\section{B. Pemeliharaan Hak Asuh Anak Menurut Hukum Islam}

Dalam kajian Hukum Islam (fiqh), pemeliharaan anak biasa disebut atau diistilahkan dengan hadhanah. Hadhanah ialah yang berarti memelihara seorang anak yang belum mampu hidup mandiri meliputi pendidikan dan segala sesuatu diperlukannya baik dalam bentuk melaksanakan maupun dalam bentuk menghindari sesuatu yang dapat merusaknya. ${ }^{11}$ Ulama berpendapat bahwa hadhanah adalah hak orang yang dipelihara. Jika ia menggugurkannya maka gugurlah hak hadhanah itu. Adapun menurut pendapat ulama yang ahli dibidangnya, hadhanah itu berkaitan dengan tiga hak secara bersamaan, yaitu hak orang yang yang memelihara, hak orang yang dipelihara, dan hak ayah atau orang yang bertindak selaku wakilnya. Jika ketiganya mampu digabungkan maka wajib dilakukan. Namum apabila bertentangan maka yang didahulukan adalah hak orang yang dipelihara. ${ }^{12}$

Hadhanah adalah salah satu bentuk dari kekuasaan dan kepemimpinan. Namun demikian, dalam hal ini perempuan lebih layak untuk menempatinya karena kaum hawa bisa lebih lembut, penuh kasih sayang, dan sabar dalam

${ }^{11}$ Ali Zainuddin, Hukum Perdata Islam Di Indonesia, (Jakarta: Sinar Grafika, 2007), hlm. 67.

\footnotetext{
${ }^{12}$ Wahbah Az-Zuhaili, Fiqih Islam..., hlm. 60.
} 
mendidik. Jika si anak sudah mencapai usia tertentu maka hak pemeliharaannya di limpahkan kepada lelaki, karena ia lebih mampu menjaga dan mendidik si anak dari pada kaum wanita. Dimana pada dasarnya orang tualah yang bertanggung jawab atas pemeliharaan anak-anaknya, baik orang tua yang dalam keadaan rukun maupun dalam keadaan sudah bercerai. Allah SWT memberi perintah kepada umat manusia untuk senantiasa menjaga dirinya dari perbuatan-perbuatan dosa yang biasa menjerumuskannya kedalam api neraka. Keselamatan besok di akhirat tidak hanya menjadi tanggung jawab bersama seluruh keluarga. ${ }^{13}$

Dari beberapa defenisi diatas, dapat disimpulkan bahwa yang dimaksud dengan hadhanah adalah mengasuh atau memelihara anak yang belum mumayiz supaya menjadi manusia yang hidup sempurna dan tanggung jawab. Hadhanah diartikan dengan pemeliharaan dan pendidikan. Yang dimaksud mendidik dan memelihara disini adalah menjaga, memimpin, dan mengatur segala hal yang anak-anak itu belum sanggup mengatur sendiri. ${ }^{14}$

Hadhanah merupakan hak bersama antara kedua orang tua serta anakanak, sehingga apabila nantinya timbul permasalahan dalam hadhanah, maka yang diutamakan adalah hak anak. ${ }^{15}$

\section{Pemeliharaan Hak Asuh Anak Menurut Undang-Undang}

Dalam Undang-Undang No. 1 Tahun 1974 tentang Perkawinan telah disebutkan tentang hukum penguasaan anak secara tegas yang merupakan rangkaian dari hukum perkawinan di Indonesia, akan tetapi hukum penguasaan anak itu belum diatur dalam Peraturan Pemerintah Nomor 9 Tahun 1975 secara luas dan rinci. Oleh karena itu, masalah penguasaan anak (hadhanah) ini belum dapat diberlakukan secara efektif sehingga para hakim di lingkungan Peradilan Agama pada waktu itu masih mempergunakan hukum hadhanah yang tersebut dalam Kitab-Kitab Fikih ketika memutus perkara yang berhubungan dengan hadhanah itu. Setelah diberlakukan Undang-Undang Nomor 7 Tahun 1989 tentang Peradilan Agama, dan Inpres Nomor 1 Tahun 1991 tentang penyebarluasan

\footnotetext{
13 Tihami dan Sohari Sahrani, Fikih Munakahat..., hlm. 216.

${ }^{14}$ Syaikh Hasan Ayyub, Fiqh Keluarga, (Jakarta: Pustaka Al-Kautsar, 2004), hlm. 391.

${ }^{15}$ Wahbah Az-Zuhaili, Fiqih Islam..., hlm. 279.
} 
Kompilasi Hukum Islam, masalah hadhanah menjadi hukum positif di Indonesia dan Peradilan Agama diberi wewenang untuk menjadi dan menyelesaikannya. ${ }^{16}$

Dalam Undang-Undang Nomor 1 Tahun 1974 tentang Perkawinan Pasal 42-45 dijelaskan bahwa orang tua wajib memelihara dan mendidik anak-anaknya yang belum mencapai umur 18 tahun dengan cara yang baik sampai anak itu kawin atau dapat berdiri sendiri. Kewajiban ini berlaku terus meskipun perkawinan antara orang tua si anak putus karena perceraian atau kematian. Kekuasaan orang tua juga meliputi untuk mewakili anak tersebut mengenai segala perbuatan hukum di dalam dan di luar pengadilan. Kewajiban orang tua memelihara anak meliputi pengawasan (menjaga keselamatan jasmani dan rohani) pelayanan (memberi dan menanamkan kasih sayang) dan pembelajaran dalam arti yang luas yaitu kebutuhan primer dan sekunder sesuai dengan kebutuhan dan tingkat sosial ekonomi orang tua si anak. Ketentuan ini sama dengan konsep hadhanah dalam hukum Islam, dimana dikemukakan bahwa orang tua berkewajiban memelihara anak-anaknya, semaksimal mungkin dengan sebaikbaiknya. ${ }^{17}$

Dalam kaitan ini, Kompilasi Hukum Islam Pasal 105 menjelaskan secara lebih rinci dalam hal suami istri terjadi perceraian yaitu:

a. pemeliharaan anak yang belum mumayiz atau belum berumur 12 tahun adalah hak ibunya.

b. pemeliharaan anak yang sudah mumayiz diserahkan kepada anak untuk memilih di antara ayah atau ibunya sebagai pemegang hak pemeliharaannya.

c. biaya pemeliharaan ditanggung oleh ayahnya. ${ }^{18}$

Ketentuan KHI tersebut, tampak bahwa tanggung jawab seorang ayah kepada anaknya tidak dapat gugur walaupun ia sudah bercerai dengan istrinya atau ia sudah kawin lagi. Dapat juga dipahami bahwa ketika anak itu masih kecil (belum baliqh) maka pemeliharaannya merupakan hak ibu, namun biaya

16 Abdul Manan, Penerapan Hukum Acara Perdata Di Lingkungan Peradilan Agama, (Jakarta: Kencana, 2008), hlm. 428-429.

${ }^{17}$ Abdul Manan, Penerapan Hukum, ...hlm. 429. 2007), hlm. 138

18 Abdurrahman, Kompilasi Hukum Islam Di Indonesia, (Jakarta: Akademika Pressindo, 
ditanggung oleh ayahnya. Selain itu, anak yang belum mumayyiz maka mendapat prioritas utama untuk mengasuh anaknya. Apabila anak sudah mumayyiz maka sang anak berhak memilih di antara ayah atau ibunya yang ia ikuti. Tergantung dari anak dalam menentukan pilihannya. Lain halnya bila orang tua lalai dalam melaksanakan tanggung jawab, baik dalam merawat dan mengembangkan harta anknya. Orang tua demikian dapat dicabut atau dialihkan kekuasaannya bila ada alasan-alasan yang menuntut pengalihan tersebut. Hal ini berdasarkan Pasal 49 Undang-Undang Perkawinan yang berbunyi sebagai berikut.

(1) Salah seorang atau kedua orang tua dapat dicabut kekuasaanya terhadap seorang anak atau lebih untuk waktu yang tertentu atas permintaan orang tua yang lainnya,, keluarga anak dalam garis lurus keatas dan saudara kandung yang telah dewasa atau pejabat yang berwenang, dengan keputusan Pengadilan dalam hal-hal:

(a) Ia sangat melalaikan kewajibannya terhadap anaknya;

(b) Ia berkelakuan buruk sekali.

Meskipun orang tua dicabut kekuasaanya, mereka masih tetap berkewajiban untuk memberi biaya pemeliharaan kepada anak tersebut. ${ }^{19}$

\section{Dasar Hukum Hadhanah}

Setiap produk hukum pastilah selalu didasarkan dengan hukum yang mempertimbangkan akan kedudukan produk hukum tersebut, tidak terkecuali dengan hadhanah. Berikut yang menjadi landasan hukum terhadap eksistensi hadhanah (pemeliharaan anak). Pertama, firman Allah SWT dalam surat atTahrim ayat 6;

Artinya : "Hai orang-orang yang beriman, peliharalah dirimu dan keluargamu dari api neraka yang bahan bakarnya adalah manusia dan batu...". (QS AlTahrim [66]:6)

Maksud ayat diatas adalah orang tua diperintahkan Allah Swt. Untuk memelihara keluarganya dari api neraka, dengan berusaha agar seluruh anggota

${ }^{19}$ Ali Zainuddin, Hukum Perdata ..., hlm. 68. 
keluarganya itu melaksanakan perintah-perintah dan larangan-larangan Allah, termasuk anggota keluarga dalam ayat ini adalah anak.

Pemeliharaan anak juga mengandung arti sebuah tanggung jawab orang tua untuk mengawasi, memberi pelayanan yang semestinya serta mencukupi kebutuhan hidup dari seorang anak oleh orang tua. Tanggung jawab pemeliharaan berupa pengawasan dan pelayanan serta pencukupan nafkah anak sampai anak tersebut mencapai batas umur orang dewasa yang telah mampu berdiri sendiri. ${ }^{20}$

Undang-undang perkawinan saat ini belum mengatur secara khusus tentang pengawasan anak sehingga pada waktu sebelum tahun 1989, para hakim masi menggunakan kitab-kitab fikih. Barulah setelah diberlakukannya UU No. 7 Tahun 1989 tentang Peradilan Agama dan Inpres No. 1 Tahun 1991 tentang penyebarluasan KHI, masalah Hadhanah menjadi hukum positif di Indonesia dan Peradilan Agama diberi wewenang untuk memeriksa dan menyelesaikannya. ${ }^{21}$

\section{E. Yang Berhak Melakukan Pemeliharaan Anak (Hadhanah)}

Seorang anak pada permulaan hidupnya sampai pada umur tertentu, memerlukan orang lain untuk membantunya dalam kehidupannya, seperti makan, pakaian, membersihkan diri, bahkan sampai kepada pengaturan bangun tidur. Oleh karena itu, orang yang menjaganya perlu mempunyai rasa kasih sayang, kesabaran, dan mempunyai keinginan agar anak itu baik (saleh) dikemudian hari. Disamping itu, ia harus mempunyai waktu yang cukup pula untuk melakukan tugas itu. Dan orang yang memiliki syarat-syarat tersebut adalah wanita. Oleh karna itu, agama menetapkan bahwa wanita adalah orang yang sesuai dengan syarat-syarat tersebut. Hak ibu terhadap anak lebih kuat dari pada hak ayah. Menurut mazhab Imam Syafi'i, masa hadhanah anak, baik laki-laki maupun perempuan, berakhir ketika sampai usia tujuh tahun atau delapan tahun. Jika telah sampai usia tersebut dan ia termasuk yang berakal sehat, maka ia dipersilakan untuk memilih antara ayah dan ibunya. Ia berhak untuk ikut siapa saja di antara mereka yang ia pilih. ${ }^{22}$

\footnotetext{
${ }^{20}$ Ali Zainuddin, Hukum Perdata..., hlm. 68.

${ }^{21}$ Ali Zainuddin, Hukum Perdata ..., hlm. 299.

${ }^{22}$ Huzaemah Tahido Yanggo, Fikih Perempuan Kontemporer, (Jakarta: Ghalia Indonesia, 2010), hlm. 186-187.
} 
Orang yang berhak memelihara anak dari pihak perempuan dan laki-laki menurut 4 Ulama Mazhab:

a. Perempuan: ibu, ibunya ibu, ibunya ayah, kakek dari ibu, saudara perempuan, bibi dari ibu, kemudian putri-putri saudara lelaki, putri-putri saudara perempuan, bibi dari ayah, kemudian setiap orang yang termasuk mahram dan berhak mendapat warisan sebagai ashabah sesuai urutan waris. Pendapat ini seperti pendapat Hanafiyyah.

b. Laki-laki: jika ada dua orang yang satu tingkat dalam kekerabatan dan kedekatan, seperti dua orang saudara lelaki atau perempuan, atau dua bibi dari ayah dan dari ibu maka cara pilihannya dengan mengundi karena tidak mungkin memilih keduanya untuk menjadi pengasuh atau memelihara anak secara bersamaan. Dan juga tidak ada keistimewaan dari salah satu keduanya, jadi pemilihannya harus dengan mengundi.

Dasar urutan orang-orang yang berhak melakukan hadhanah diatas ialah:

a. Kerabat pihak ibu didahulikan atas kerabat pihak bapak jika tingkatannya dalam kerabat adalah sama.

b. Nenek perempuan didahulukan atas saudara perempuan karena anak merupakan bagian dari kakek, karena itu nenek lebih berhak dibanding dengan saudara perempuan.

c. Kerabat sekandung didahulukan dari kerabat yang bukan sekandung dan kerabat seibu lebih didahulukan atas kerabat seayah.

d. Dasar urutan ini ialah urutan kerabat yang ada hubungan mahar, dengan ketentuan bahwa pada tingkat yang sama pihak ibu didahulukan atas pihak bapak.

e. Apabila kerabat yang ada hubungan mahram tidak ada, maka hak hadhanah pindah kepada kerabat yang tidak ada hubungan mahram.

Ulama memberikan urutan dan skala prioritas hak mengasuh anak bagi para wanita, sesuai dengan kemaslahatan anak tersebut. Ketika pengasuhan menjadi hak dasar ibu, maka para ulama menyimpulkan, kerabat ibu lebih diutamakan dari pada kerabat ayah.

Bila salah seorang ibu dan ayah ingin melakukan perjalanan yang akan kembali pada waktunya, sedangkan yang satu lagi menetap di tempat lebih berhak 
mendapatkan hadhanah. Alasannya ialah, bahwa perjalanan itu mengandung resiko dan kesulitan bagi sianak. Oleh karena itu menetap lebih baik karena tidak ada resiko tersebut bagi sianak.

Dalam Kompilasi Hukum Islam Pasal 156 huruf (a) anak yang belum mumayiz berhak mendapatkan hadhanah dari ibunya, kecuali bila ibunya telah meninggal dunia, maka kedudukannya digantikan oleh:

a. wanita-wanita dalam garis lurus dari ibu;

b. ayah;

c. wanita-wanita dalam garis lurus ke atas dari ayah;

d. saudara perempuan dari anak yang bersangkutan;

e. wanita-wanita kerabat sedarah menurut garis samping dari ibu;

f. wanita-wanita kerabat sedarah menurut garis samping dari ayah. ${ }^{23}$

\section{F. Syarat-Syarat Pemeliharaan Anak (Hadhanah)}

Masalah hak asuh anak merupakan masalah yang sangat penting untuk dilaksanakan, oleh karena itu orang yang melaksanakan hak asuh anak itu haruslah mempunyai kecakapan dan kecukupan serta perlu adanya syarat-syarat tertentu yang harus dipenuhi diantaranya:

a. Syarat-syarat Hak Asuh Anak Dari Pihak Ibu

Seorang ibu yang mengasuh anaknya harus memiliki persyaratanpesyaratan yang harus di penuhi, syarat tersebut antara lain:

1) Berakal sehat, bagi orang yang kurang sehat akalnya atau gila, tidak boleh menangani hadhanah karena mereka tidak dapat mengurus dirinya sendiri, maka ia tidak boleh diserahi mengurus orang lain.

2) Dewasa, hal ini karena anak kecil sekalipun mumayyiz, tetap membutuhkan orang lain yang mengurusinya dan mengasuhnya, karena itu dia tidak boleh menangani orang lain.

3) Mampu mendidik, tidak buta atau rabun, sakit menular atau sakit yang melemahkan jasmaninya, bukan orang yang tinggal bersama orang yang sakit menular, atau bersama orang yang suka marah kepada anak-anak,

23 Abdurrahman, Kompilasi Hukum..., hlm. 138. 
sehingga akibat kemarahannya itu tidak bisa memperhatikan kepentingan si anak secara sempurna dan menciptakan suasana yang kurang baik.

4) Amanah dan berbudi, sebab orang yang curang tidak dapat dipercaya untuk menunaikan kewajiban dengan baik, bahkan dikhawatirkan bila nantinya si anak dapat meniru atau berkelakuan seperti kelakuan orang yang curang itu.

5) Islam, anak kecil muslim tidak boleh diasuh oleh pengasuh yang bukan muslim sebab hak asuh anak merupakan masalah perwalian, sedangkan Allah tidak membolehkan seorang mukmin di bawah perwalian kafir. Tugas mengasuh termasuk kedalamnya usaha mendidik anak menjadi muslim yang baik, dan hal itu menjadi kewajiban mutlak atas kedua orang tua.

6) Ibunya belum menikah lagi, karena jika ibunya menikah lagi dengan lakilaki lain maka hak asuh anaknya akan hilang. Adanya persyaratan tersebut disebabkan kekhawatiran suami kedua tidak merelakan istrinya disibukkan mengurus anaknya dari suami pertama. Oleh karena itu ahli-ahli fiqih menyimpulkan, hak hadhanah tidak menjadi gugur jika ia menikah dengan kerabat dekat si anak.

7) Merdeka. Sebab orang budak biasanya sangat sibuk dengan urusan-urusan dengan tuanya, sehingga ia tidak memiliki kesempatan untuk mengasuh anak kecil.

b. Syarat-syarat Hak Asuh Anak Dari Pihak Ayah

Seorang ayah yang mengasuh anaknya juga harus memiliki persyaratan yang harus dipenuhi, syarat tersebut antara lain:

1) Berakal sehat, orang yang tidak sehat akalnya tidak diperkenankan merawat anak.

2) Dewasa, anak kecil tidak diperkenankan menjadi hak asuh anak sebab ia sendiri masih membutuhkan perawatan orang lain.

3) Mampu mendidik, orang yang rabun matanya atau tuna netra, punya penyakit menular, usia lanjut, dan mempunyai tabiat suka marah-marah kepada anak-anak meskipun kerabat anak kecil itu sendiri dilarang menjadi orang yang melakukan hak asuh anak. 
4) Amanah dan berbudi, sebab orang yang curang tidak dapat dipercaya untuk menunaikan kewajiban dengan baik, bahkan dikhawatirkan bila nantinya si anak dapat meniru atau berkelakuan seperti kelakuan orang yang curang ituDapat menjamin pemeliharaan dan pendidikan anak terutama yang berhubungan dengan budi anak.

5) Islam, anak kecil muslim tidak boleh diasuh oleh pengasuh yang bukan muslim sebab hak asuh anak merupakan masalah perwalian, sedangkan Allah tidak membolehkan seorang mukmin di bawah perwalian kafir.

6) Ayahnya dapat menikah lagi, di dalam islam tidak ada yang melarang bagi suami untuk menikah lagi meskipun dia mengasuh anaknya.

7) Merdeka. Sebab orang budak biasanya sangat sibuk dengan urusan-urusan dengan tuanya, sehingga ia tidak memiliki kesempatan untuk mengasuh anak kecil.

Adapun perbedaan dari syarat-syarat Hadhanah diatas ialah ibunya dalam kondisi yang belum menikah lagi dan ayahnya dapat menikah lagi.

c. Adapun syarat untuk anak yang diasuh (mahdhun) itu adalah:

1) Si anak masih dalah usia kanak-kanak dan belum dapat berdiri sendiri dalam mengurus hidupnya.

2) Si anak berada dalam keadaan tidak sempurna akalnya. Oleh karena itu, dapat berbuat sendiri, meskipun telah dewasa seperti orang yang cacat mental. Orang yang telah dewasa dan sehat sempurna akalnya tidak boleh berada dibawah pengasuhan apapun. ${ }^{24}$

\section{G. Upah Pemeliharaan Anak (Hadhanah)}

Ibu tidak berhak atas upah hadhanah dan menyusui, selama ia masi menjadi istri dari ayah anak kecil itu, atau selama masi dalam idah, Karena dalam keadaan tersebut ia masih mempunyai nafkah sebagai istri atau nafkah masa idah. ${ }^{25}$ Adapun jika statusnya selain ibu dari si anak maka nafkahnya ditanggung ayahnya. Akan tetapi jika anak yang dipelihara membutuhkan bantuan lain,

\footnotetext{
${ }^{24}$ Sayyid Sabiq, Fiqh Sunnah, jilid 2, (Beirut: Dar Fikr,1983) h. 242.

25 Tihami dan Sohari Sahrani, Fikih Munakahat..., h. 225.
} 
seperti memasak dan mencuci pakaian maka hadhin berhak mendapatkan upah. Allah Swt. Berfirman dalam surat Al-Baqarah ayat 233:

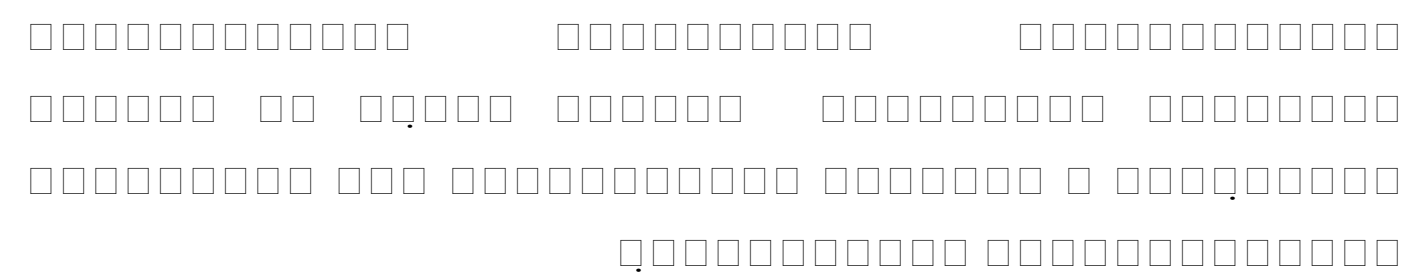

Artinya: Para ibu hendaklah menyusukan anak-anaknya selama dua tahun penuh, yaitu bagi yang ingin menyempurnakan penyusuan. Dan kewajiban ayah memberi makan dan pakaian kepada para ibu dengan cara ma'ruf.

Adapun sesudah habis iddahnya, maka ia berhak atas upah itu seperti haknya kepada upah menyusui, sebagaimana Allah SWT, berfirman dalam surat Al-Thalaq ayat 6:

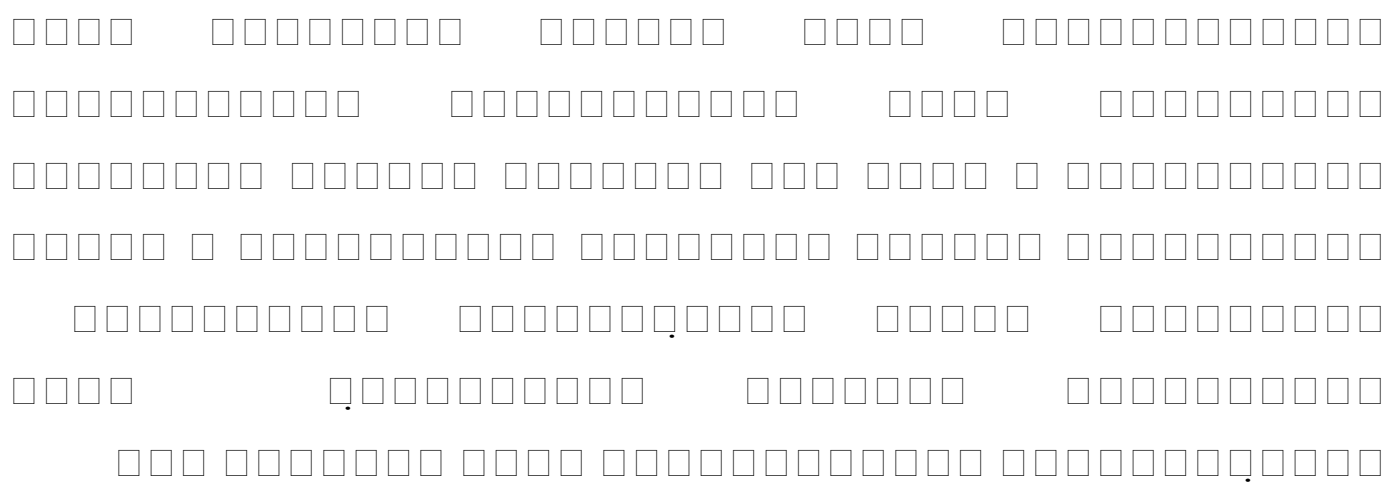

Artinya: Maka berikanlah kepada mereka upahnya, dan musyawarahkanlah di antara kamu (segala sesuatu) dengan baik; dan jika kamu menemui kesulitan maka perempuan lain boleh menyusukan (anak itu) untuknya.

Perempuan selain ibunya si anak boleh menerima upah hadhanah sejak ia menangani hadhanah-nya, seperti halnya perempuan penyusu yang berkerja menyusui anak kecil dengan bayaran (upah).

Ibu yang berhak memelihara anaknya apakah harus menyusuinya apabila anak dalam usia menyusu? Ada dua pendapat, salah satunya berpendapat, tidak harus, tetapi harus memeliharanya. Kalau ibu tidak menyusui anaknya, baik karena air tidak keluar atau ia memutuskan tidak menyusui, maka ayahnya harus 
mengupahkan orang untuk menyusuinya. Demikian menurut pendapat Al-Baghwy ulama mazhab Syafi'i. ${ }^{26}$

Kompilasi Hukum Islam juga melakukan antisipasi jika kemungkinan seorang bayi disusukan kepada perempuan yang bukan ibunya sebagaimana dikemukakan dalam pasal 104 yaitu:

a. semua biaya penyusuan anak dipertanggungjawabkan kepada ayah. Apabila ayahnya meninggal dunia, maka biaya penyusuan dibebankan kepada orang yangberkewajiban memberi nafkah kepada ayahnya atau walinya;

b. penyusuan dilakukan paling lama dua tahun dan dilakukan penyapihan dalam masa kurang dua tahun dengan persetujuan ayahnya. ${ }^{27}$

Antisipasi ini sangat positif sebab meskipun ibu yang harus menyusui anaknya tetapi dapat diganti dengan susu kaleng atau anak disusukan oleh seorang ibu yang bukan ibunya sendiri. Ketentuan ini juga relevan dengan hal yang terdapat dalam ayat 233 surat Al-Baqarah yang menjadi acuan dalam hal pemeliharaan anak. ${ }^{28}$

Seorang ayah wajib membayar upah penyusuan dan hadhanah. Ia juga wajib membayar ongkos sewa rumah atau perlengkapannya jika sekiranya si ibu tidak memiliki rumah sendiri sebagai tempat mengasuh anak kecilnya. Ia juga wajib membayar gaji pembantu rumah tangga atau menyediakan pembantu tersebut jika si ibu membutuhkannya, dan ayah memiliki kemampuan untuk itu. Hal ini bukan termasuk dalam bagian nafkah khusus bagi anak kecil, seperti makan, minum, tempat tidur, obat-obatan, dan keperluan pokok lainnya yang sangat dibutuhkannya, tetapi, upah ini hanya wajib dikeluarkannya saat ibu pengasuh mengasuh asuhannya. Dan upah ini menjadi utang yang ditanggung oleh ayah serta bisa lepas dari tanggungan ini kalau dilunasi atau dibebaskan. Jika di antara kerabat anak kecil ada orang yang pandai mengasuhnya dan melakukannya dengan sukarela, sedangkan ibunya sendiri tidak mau, kecuali kalau dibayar, maka jika ayahnya mampu, dia boleh di paksa untuk membayar

26 Abdul Fatah Idris dan Abu Ahmadi, Fikih Islam Lengkap, (Jakarta: Rineka Cipta, 2004) hlm. 295.

${ }^{27}$ Kompilasi Hukum Islam, BAB XIV Tentang Pemeliharaan Anak, Pasal 104.

28 Abdurrahman, Kompilasi Hukum..., hlm. 138. 
upah kepada ibunya tersebut dan ia tidak boleh menyerahakan kepada kerabatnya perempuan yang mampu mengasuhnya dengan sukarela. Bahkan, si anak kecil harus tetap pada ibunya. Sebab, asuhan ibunya lebih baik untuknya apabila ayahnya mampu membayarnya untuk upah ibunya. Tetapi, kalau ayahnya tidak mampu, ia boleh menyerahkan anak kecil itu kepada kerabatnya yang perempuan untuk mengasuhnya dengan sukarela, dengan syarat kerabat perempuannya itu pandai mengasuhnya. Hal ini berlaku apabila nafkah itu wajib ditanggung oleh ayahnya. Adapun apabila anak kecil itu sendiri memiliki harta untuk membayar nafkahnya diberikan kepada kerabatnya yang bertugas sebagai penjaga dan pengasuhnya bagi dirinya dan hartanya. Namun, jika ayahnya tidak mampu, sedangkan si anak kecil sendiri juga tidak memiliki harta, dan ibunya tidak mau mengasuhnya kecuali kalau dibayar maka ibu dapat dipaksa untuk mengsuhnya,sedangkan upah (bayarannya) menjadi utang yang wajib dibayar oleh ayahnya, dan bisa gugur kalau telah dibayar atau dibebaskan. ${ }^{29}$

Anak mempunyai kedudukan tertentu terhadap keluarganya, orang tua berkewajiban untuk memberikan nafkah hidup, pendidikan yang cukup, memelihara kehidupan anak tersebut sampai ia dewasa atau sampai ia dapat berdiri sendiri mencari nafkah. Anak merupakan tumpuan harapan orang tuanya dan sekaligus menjadi penerus keturunannya. ${ }^{30}$

\section{H. Masa Berlaku Pemeliharaan Anak dan Hukum Setelahnya.}

Hadhanah itu berlaku ketika anak tersebut masih kecil dan berakhirnya masa hadhanah ketika anak sudah mampu berfikir atau sudah mampu untuk menikah. Dalam literatur fiqih disebutkan dua periode anak dalam hadhanah, yaitu masa sebelum mumayyiz dan sesudah mumayyiz kaitannya dengan itu adalah: 31

a. Periode sebelum mumayyiz

Periode ini dimulai dari waktu anak itu lahir sampai menjelang umur tujuh tahun atau delapan tahun. Pada masa tersebut anak masih dikatakan belum mumayyiz, karena masih belum bisa membedakan antara yang bermanfaat dengan

29 Abdurrahman, Kompilasi Hukum,... hlm. 225.

${ }^{30}$ Abdul Manan, Aneka Masalah..., hm. 80.

${ }^{31}$ Satria Effendi M. Zein, Problematika Hukum Keluarga Islam Kontemporer..., hlm. 181. 
yang berbahaya bagi dirinya. Adanya syarat-syarat sebagai pengasuh pada periode ini, ulama menyimpulkan bahwa pihak ibu lebih berhak terhadap anak untuk selanjutnya melakukan kewajiban hadhanah. Karena anak pada masa itu masih membutuhkan untuk hidup di dekat ibunya, ${ }^{32}$ dan tidak ada batasan waktu tertentu mengenai habisnya, hanya saja ukuran yang dipakai adalah mumayyiz dan kemampuan berdiri sendiri, jika ia telah dapat membedakan ini dan itu serta dapat memenuhi kebutuhan pokoknya sendiri maka hadhanahnya berakhir. ${ }^{33}$ Para ulama berbeda pendapat mengenai batasan umur bagi laki-laki dan perempuan adalah

Ulama Hanafiyyah berpendapat bahwa masa berakhirnya hadhanah itu ketika anak laki-laki berumur 7 (tujuh) tahun dan 9(sembilan) tahun atau 11 (sebelas) tahun. ${ }^{34}$ Hadhanah anak laki-laki berakhir pada saat anak itu tidak lagi memerlukan penjagaan dan telah dapat mengurus keperluannya sehari-hari seperti makan, minum dan sebagainya. Sedang masa hadhanah wanita berakhir apabila ia telah baligh atau telah datang masa haidnya pertamanya. ${ }^{35}$

Ulama Malikiyyah juga berpendapat bahwa masa hadhanah bagi anak lakilaki sampai ia baligh, meskipun anak itu gila ataupun sakit. Sedangkan anak perempuan masa hadhanah sampai ia menikah, meskipun ibunya kafir. Menurut pendapat Hanafiyyah dan Malikiyyah, seorang anak tidak diminta untuk memilih pengasuh, karena pada masa itu anak belum bisa menentukan pilihan dengan akal sehatnya dan umur anak yang masih kecil. ${ }^{36}$

Kemudian menurut Ulama Syafi'iyyah bahwa masa hadhanah itu berakhir ketika berumur sampai usia 7-8 tahun. Jika suami istri bercerai dan punya anak yang sudah mumayyiz, yaitu yang menginjak umur tujuh sampai delapan tahun dan anak termasuk yang berakal sehat. Karena kedua orang tuanya sama-sama layak untuk mengurus hadhanah, tetapi jika dari keduanya saling berebut untuk mengasuh, maka anak dibolehkan untuk memilih salah satu di antara kedua orang

32 Satria Effendi M. Zein, Problematika Hukum Keluarga Islam Kontemporer..., hlm. 181.

${ }^{33}$ Aris Bintania, Hukum Acara..., hlm. 242.

34 Wahbah Az-Zuhaili, Fiqih Islam..., hlm. 79.

35 Syamsuddin Abu Bakar Muhammad al-Sarkhasi, al-Mabsuth, jilid 5, (Beirut: Dar alMa'rifah, t.th), hlm. 223

${ }^{36}$ Malik bin Anas Al-Ashbahi, Al-Mudawwanah Al-Kubra, jilid 2, (Beirut: Darul Kutub Al-Ilmiyah, 1994), hlm. 263. 
tuanya. ${ }^{37}$ Sedangkan menurut pendapat Hanabilah, ia pun sependapat dengan Syafi'iyyah yaitu apabila anak laki-laki yang sudah berumur tujuh tahun dan telah mencapai usia tersebut, maka anak dipersilahkan untuk memilih diantara kedua orang tuanya. ${ }^{38}$ Adapun anak perempuan jika sudah mencapai umur tujuh tahun atau lebih maka sang ayah lebih berhak sampai ia baligh dan untuk mengurusnya tanpa diberi kesempatan untuk memilih. ${ }^{39}$

Setelah dikemukakan perbedaan pendapat para ulama fiqih di atas mengenai batasan masa hadhanah, maka dari hal tersebut tidak ada yang menerangkan secara jelas mengenai masa pengasuhan anak, hanya saja para ulama sepakat bahwa masa hadhanah itu dimulai sejak kelahiran anak sampai usia mumayyiz, sebab pada hadhanah anak sudah terdapat upaya memelihara kemaslahatan anak dalam naungan bimbingan dan pemeliharaan orang tuanya. ${ }^{40}$ Oleh karena itu adanya perbedaan pendapat tersebut, maka dari ketentuan Undang-undang menyerahkannya kepada kebijaksanaan dan keputusan hakim dengan memberikan ketentuan mengenai batasan akhir umur anak ketika hak asuh itu diberikan, namun hal ini harus sejalan dengan pedoman bahwa kemaslahatan anak lebih diutamakan. ${ }^{41}$ Dalam ketentuan Undang-undang juga tidak dijelaskan secara rinci umur masing-masing anak, baik itu anak laki-laki maupun perempuan, tetapi dari hal tersebut menjelaskan batasan umur anak terakhir dibawah pengasuhan orang tuanya, seperti yang dijelaskan dalam KHI pasal 105 huruf (a). Di dalam Undang-undang perkawinan terdapat perbedaan mengenai umur pencapaian anak yang belum mumayyiz. Sebagaimana dijelaskan dalam pasal 47 ayat 1 .

Mengenai usia anak yang belum mumayyiz maka tidak menjadi alasan untuk tidak mengasuhnya, karena sebagai orang tua ataupun pengasuh tetap yang didahulukan hak anak bukan masing-masing yang memiliki kekuasaan terhadap anak. Sehingga anak yang belum mumayyiz tetap merupakan kewajiban bagi

\footnotetext{
${ }^{37}$ Muhammad Bin Idris Asy-Syafi'i, Al-Umm, jilid 7, (Beirut: Dar Al-Ma'rifah, t.th), hlm. 340 .

${ }^{38}$ Ibnu Qudamah, Al-Mughni, jilid 8, (Riyadz: Dar 'Alamal Kutub, t.th ), hlm. 171.

39 Jaih Mubarok, Peradilan Agama Di Indonesia, (Bandung: Pustaka Bani Quraisy, 2004), hlm. 196.

${ }^{40}$ Huzaemah Tahido Yanggo, Fiqih Anak, Cet. 1, hlm. 115.

${ }^{41}$ Direktorat Jenderal Pembinaan Kelembagaan Agama Islam Departemen Agama, Ilmu
} Fiqh, Jilid 2, Cet. 2, hlm. 215. 
orang tuanya untuk merawat, mendidik, memelihara sampai anak itu dewasa dan menikah.

b. Periode Mumayyiz

Masa mumayyiz adalah dari umur tujuh tahun sampai ia baligh berakal. Pada masa ini seorang anak secara sederhana telah mampu membedakan masa yang berbahaya dan mana yang bermanfaat bagi dirinya. Oleh karena itu anak sudah dianggap mampu menjatuhkan pilihannya sendiri untuk memilih seseorang yang berhak mengasuhnya, apakah ia akan ikut ibu atau bapaknya. ${ }^{42}$ Sebagaimana dijelaskan dalam pasal 105 huruf (b) bahwa seorang anak yang sudah mumayyiz boleh menentukan pilihan diantara ayah atau ibunya sebagai pemegang hak pemeliharaannya. Akan tetapi apabila dalam satu kondisi dimana pilihan anak itu tidak menguntungkan bagi dirinya, maka yang berhak menentukan siapa yang paling berhak melakukan hadhanah pada orang-orang yang memiliki kualifikasi sama adalah Qadhi yaitu hakim Pengadilan Agama. ${ }^{43}$ Sebagaimana telah diatur juga dalam pasal 156 huruf (c) menjelaskan, apabila pemegang hadhanah ternyata tidak dapat menjamin keselamatan anaknya, maka pengadilan agama dapat memindahkan hak hadhanah kepada kerabat lain yang mempunyai hak atas itu.

Disamping itu seseorang yang akan melakukan hadhanah harus mempunyai kemampuan dan kemauan untuk memelihara serta mendidik anaknya agar tidak mengakibatkan anak menjadi terlantar. ${ }^{44}$ Pengasuhan berakhir apabila seorang anak sudah mencapai umur dewasa yang dapat mampu berfikir dewasa dan sampai ia menikah. Sedangkan untuk mencapai kemaslahatan anak maka masing-masing dari orang tua untuk mampu mengendalikan dirinya dari penguasaan anak, karena bagi seseorang yang berhak melakukan hadhanah sama sekali tidak menggambarkan anak hanya menjadi miliknya yaitu dari masingmasing orang tua melainkan hak hadhanah itu milik bersama kedua orang tua,

${ }^{42}$ Satria Effendi M. Zein, Problematika Hukum..., h. 182.

${ }^{43}$ Huzaemah Tahido Yanggo, Fiqih Anak,... hlm. 119.

${ }^{44}$ Satria Effendi M. Zein, Problematika Hukum Keluarga Islam Kontemporer..., hlm. 184. 
yang merupakan kewajiban untuk memelihara serta mendidik anak-anaknya yang kemudian mengantarkan anak ke masa depan yang cemerlang. ${ }^{45}$

\section{Hukum Yang Timbul Setelah Selesainya Masa Pemeliharaan Anak (Hadhanah)}

Jika masa hadhanah anak telah selesai maka ia dikembalikan pada ayah atau kakeknya. Mulai saat itu, sang ayah berhak mengurus si anak hingga usia baligh untuk kemudian diberi pilihan, apakah ingin sendiri atau memilih hidup bersama salah satu dari kedua orang tua. Terkecuali jika si anak itu memiliki keterbatasan mental dan tidak mampu mengurus dirinya sendiri, anak tersebut diurus oleh ayah untuk mencegah terjadinya fitnah atau sejenisnya, dan juga untuk mendidik jika terjadi sesuatu yang tidak diinginkan. Setelah anak baliqh, ayah tidak wajib memberi nafkah kepadanya, namun tetap boleh mengurus segala keperluannya. Jika si anak tumbuh dalam keadaan keterbatasan mental maka sang ibu lebih berhak mengurusnya, baik anak lelaki maupun perempuan

Adapun bagi anak perempuan setelah masa hadhanah habis, ia ikut bersama ayah atau kakeknya jika memang masi perawan, atau sudah janda tetapi di khawatirkan terjadi fitnah. Akan tetapi tidak khawatir fitnah, akhlaknya baik, pemikirannya lurus, dan sudah berusia empat puluh tahun maka ia boleh hidup sendirian. Sang ayah tidak wajib memberi nafkah kepada putrinya jika ia menolak tinggal bersamanya, atau ikut bersamanya tetapi sebenarnya ia tidak berhak.

Kesimpulannya: jika anak lelaki sudah baliqh, demikian juga anak perempuan baik perawan maupun janda tetapi mereka tidak dapat dipercaya, maka mereka harus tinggal bersama sang ayah tanpa di beri pilihan untuk hidup sendiri. ${ }^{46}$

Berakhirnya masa asuhan atau dibebaskan untuk memilih adalah pada waktu anak itu sudah mumayyiz atau sudah bisa ditanya dan memilih kepada siapa dia akan terus ikut. Jadi secara umum anak yang belum mumayyiz hak asuh diberikan kepada ibunya. Melihat ketentuan Undang-undang Perlindungan Anak Undang-undang No. 23 tahun 2002 jo. Udang-undang No. 35 tahun 2014 bahwa hak asuh di samping hak orang tua juga merupakan hak anak, karena anak

\footnotetext{
${ }^{45}$ Huzaemah Tahido Yanggo, Fiqih Anak,...h. 202.

${ }^{46}$ Wahbah Az-Zuhaili, Fiqih Islam ..., hlm. 81.
} 
termasuk salah satu anggota keluarga. Hal tersebut diterangkan dalam pasal 37 ayat (1) yaitu: "Pengasuhan anak ditujukan kepada anak yang orang tuanya tidak dapat menjamin tumbuh kembang anaknya secara wajar". ${ }^{47}$

J. Metode yang digunakan Hakim dalam mengambil keputusan tentang pemeliharaan Hak Asuh Anak di Mahkamah Syar'iyah dalam Putusan Perkara No.150/Pdt.G/2015/ Makamah Syar'iyah Langsa

Dalam penelitian ini penulis mewawancarai Hakim yang ada di Mahkamah Syar'iyah Langsa, dimana hakim tersebut yang memiliki pengaruh sangat besar terhadap perkara Hadhanah ini. Pada umumnya setiap orang memiliki pandangan yang berbeda terhadap peraturan yang terdapat dalam Kompilasi Hukum Islam (KHI) tentang Hadhanah. Metode yang digunakan hakim dalam mengambil satu keputusan tentang perkara ini pun sangat berpengaruh besar bagi pihak-pihak yang berperkara. Oleh sebab itu metode yang digunakan Hakim saat memutuskan perkara ini yaitu Hakim Bapak Salamat Nasution mengatakan :

"Bahwa Tergugat (ayah) tidak diberi kewenangan untuk mengasuh anak, disebabkan karena Tergugat (ayah) berkelakuan buruk yang bisa mengganggu moral dan kepribadian sianak, dan dalam perkara ini hakim menggunakan metode yuridis undang-undang mengamanahkan anak yang masi dibawah umur dibawah pengasuhan ibunya, walaupun ibunya sudah menikah lagi. Konteks fiqih dimasa lalu ibu yang sudah menikah lagi tidak mendapatkan hak asuh anaknya tetapi kalau analisa putusan di mahkamah syar'iyah karna sudah di atur di KHI secara tegas itu adalah hak ibunya dan tidak diperdebatkan lagi menikah atau tidak menikah nya lagi yang pasti perdebatannya cuma untuk kepentingan sianak, kepentingan sianak ini baik atau tidak. Tidak pun dia menikah hanya karna sebab lain bisa dialihkan." ${ }^{48}$

Oleh karena itulah hakim boleh saja menerobos apa yang ada di dalam ketentuan Undang-undang, karena hakim bukan hanya sebagai corong undangundang. Adapun yang penulis teliti juga mengenai hal tersebut, bahwa dari hasil wawancara penulis dengan hakim Mahkamah Syar'iyah Langsa menyatakan bahwa "Hak hadhanah merupakan hak ibu karena di dalam ketentuan yuridis

${ }^{47}$ Ihami dan Sohari Sahrani, Fikih Munakahat..., hlm. 219-220.

48 Wawancara Dengan Hakim Bapak Salamat Nasution, Hakim Mahkamah Syar'iyah Langsa, pada Tanggal 20 oktober 2016. 
formilnya menyebutkan hak asuh anak dibawah 12 tahun itu adalah hak ibunya", namun maksud pernyataan di atas tidak berlaku secara keseluruhan, artinya jika terdapat hal-hal buruk yang dapat dikatagorikan bisa mempengaruhi hak pengasuhan anak maka itu bisa dikesampingkan dengan sebab si pengasuh berkelakuan buruk maka dari ketentuan itu hak pengasuhan bisa dialihkan.

Oleh karena itu faktor-faktor yang dapat menghalangi pihak-pihak yang bersangkutan untuk mendapatkan hak asuh anak menurut Hakim adalah "murtad, tidak berakal sehat, tidak dewasa, tidak mampu mendidik, dan tidak mampu memenuhi kepentingan sianak".

\section{K. Hasil Penelitian}

Dalam perkara putusan hak hadhanah yang terjadi antara Penggugat (istri) dengan Tergugat (suami) di atas, dimana Majelis Hakim Mahkamah Syar'iyah Langsa yang memutus perkara tersebut telah menjatuhkan hak asuh anak kepada Penggugat (ibu) dikarenakan pihak Tergugat (bapak) telah berperlakuan tidak baik, dan dikarenakan Tergugat (bapak) pernah menyalahgunakan narkoba. Oleh karena itu terjadilah perebutan hak asuh anak dan yang seharusnya dari kedua orang tuanya bisa saling melindungi dan merawatnya secara bersama-sama. Akan tetapi dalam kepengurusan anak menjadikan perbedaan pemikiran dan penguasaan antara masing-masing orang tua dalam menuntut haknya. Maka disinilah peran dan kewenangan seorang hakim untuk meluruskan suatu perkara yang timbul di tengah masyarakatnya.

Mengenai perkara di dalam putusan No. 150/Pdt.G/2015/MS.Lgs, menurut penulis penerapan hukum yang Majelis Hakim gunakan dalam memutus perkara hak asuh anak lebih menekankan prinsip kemaslahatan baik untuk anak maupun kedua orang tua, karena dalam pengasuhan anak itu yang lebih diutamakan ialah kepentingannya, bukan kepada hak yang dimiliki oleh orang tuanya, walaupun di dalam Undang-undang dan nash Al-Qur'an menyatakan bahwa hak asuh anak merupakan hak ibunya, karena hakikatnya seorang ibu cenderung lebih memiliki sifat kasih sayang dan lemah lembut, serta mampu untuk merawat, menjaga, membimbing, dan mendidik anak dari pada seorang ayah.

Sebagaimana dijelaskan dalam pasal 49 Undang-undang No. 1 tahun 1974, disebutkan bahwa apabila salah seorang atau kedua orang tuanya telah melalaikan 
kewajibannya terhadap anak dan berkelakuan buruk, maka pengadilan agama berhak untuk mencabut kekuasaan atas pengasuhan anak dari kedua orang tuanya atau dari salah satunya. Didukung dengan pasal 156 huruf (c) Kompilasi Hukum Islam yang menyebutkan, "apabila pemegang hadhanah ternyata tidak dapat menjamin keselamatan jasmani dan rohani anak, meskipun biaya nafkah dan hadhanah telah dicukupi, maka atas permintaan kerabat yang bersangkutan Pengadilan Agama dapat memindahkan hak hadhanah kepada kerabat lain yang mempunyai hak hadhanah pula."

Pada hakikatnya sang ibu selaku penggugat yang mempunyai hak asuh terhadap anak-anaknya yang belum mumayyiz. Akan tetapi karena adanya perselisihan mengenai hak asuh anak yang terjadi antara Penggugat dan Tergugat yang disebabkan oleh perbedaan pendapat, sehingga menimbulkan perebutan hak asuh anak bagi kedua orang tuanya. Menurut penulis dalam pertimbangan hukum pada putusan tersebut, majelis hakim telah menjatuhkan hak asuh anak kepada Pergugat (ibu) bukan kepada Tergugat (ayah). Hal ini disebabkan oleh kekhawatiran Penggugat terhadap pengaruh buruk dari Tergugat yang Tergugat pernah menyalah gunakan narkoba, judi bahkan tergugat pernah di tahan oleh Polisi. Jadi faktor tersebutlah yang menjadi salah satu penghalang untuk tergugat mendapatkan hak hadhanah (yang mengasuh anak) dalam masalah pengasuhan anak.

Meskipun dalam Undang-Undang Perkawinan dan Kompilasi Hukum Islam tidak disebutkan secara jelas mengenai syarat-syarat pengasuhan anak khususnya hadhanah yang apabila seorang ibu sudah menikah lagi maka hak asuh anak atau hak pemeliharaan anak tetap dalam asuhan ibunya jika anak tersebut masih dibawah umur, lain halnya dalam kitab-kitab fiqih kebalikan dari peraturan yang ada di kompilasi hukum Islam (KHI). Akan tetapi hal tersebut bisa dikesampingkan karena hukum itu bertujuan untuk kemaslahatan terutama kemaslahatan anak dalam pengasuhan orang tuanya, selama hukum itu terdapat kemaslahatan maka disitulah hukum itu boleh diterapkan,

Menurut penulis dalam perebutan hak asuh anak semestinya tidak menjadikan prioritas utama diperuntukkan bagi kaum perempuan, tetapi juga kepada kaum laki-laki, karena kaum ayah juga patut dan berhak untuk mengasuh, 
merawat serta membimbing anak-anaknya selama anak tersebut belum dewasa atau menikah. Maka dari itu dalam sengketa pemeliharaan anak dan segala tindakan yang menyangkut diri anak harus selalu ditujukan untuk kepentingan terbaik bagi anak, dan aspek dari kepentingan itulah yang harus menjadi pertimbangan utama dalam setiap tindakan dalam menjatuhkan putusan mengenai hak asuh anak agar tercipta kesejahteraan bersama dalam merawat anak. Begitu juga dalam penyelenggaraan perlindungan terhadap moral anak, yang meliputi pembinaan, pembimbingan, dan pengalaman ajaran-ajaran lainya, setiap anak harus dijamin untuk dapat bermoral dan berbudi pekerti yang baik.

Dengan demikian adanya peran seorang hakim yang memiliki hak dalam menangani putusan, maka dari putusan perkara No.150/Pdt.G/2015/MS.Lgs mengenai kasus hak asuh anak akibat ibu menikah lagi dan ayah pengguna narkoba, bahwa dalam pertimbangannya majelis hakim sudah benar-benar mengutamakan kepentingan serta perlindungan bagi anak-anak, karena demi terwujudnya kemaslahatan pada anak dan ibu kandungnya, serta untuk terhidarnya perilaku-perilaku yang dilarang agama Islam.

Oleh sebab itu di dalam putusan tersebut hak asuh anak berada ditangan ibu, sebab di bawah asuhan ibunya anak dapat dididik dan dibimbing atas kemaslahatan atau kepentingan anak, karena dari keadaan sosial, agama dan psikologisnya pada masa mendatang anak akan lebih terjamin dengan ibunya dari pada dipihak ayahnya yang dikarenakan pernah menyalah gunakan narkoba maka tidak berhak untuk menguasai anak secara sepenuhnya.

Akan tetapi apabila seorang ayah tetap berkeinginan mengasuh anak, maka sebagai seorang ayah harus bisa berhati-hati lagi dalam merawat, menjaga dan membimbingnya serta tanpa mengurangi hak-hak yang dimiliki anak. Karenanya anak merupakan amanah Allah yang harus dilindungi dan dijaga bagi semua orang tua, terutama melindungi agama anak dari kecil sampai ia dewasa.

\section{Kesimpulan}

Berdasarkan hasil penelitian diatas mengenai putusan hakim Mahkamah Syar'iyah langsa tentang pengalihan hak asuh anak dapat diambil kesimpulan sebagai berikut : 
Pemeliharaan Hak Asuh Anak menurut Hukum Islam yaitu melakukan pemeliharaan anak yang masih kecil, baik laki-laki maupun perempuan, atau yang sudah besar tetapi belum tamyiz, menyediakan sesuatu yang menjadi kebaikannya, menjaganya dari sesuatu yang menyakiti dan merusaknya, mendidik jasmani, rohani, akhlaknya agar mampu berdiri sendiri menghadapi hidup dan memikul tanggung jawab. Adapun dalam Undang-Undang pasal 42 dan 45, mengenai ketentuan hadhanah di jelaskan bahwa kewajiban orang tua memelihara anak meliputi pengawasan, pelayanan, menanamkan kasih sayang dalam arti luas yaitu kebutuhan primer dan sekunder sesuai dengan kebutuhan dan tingkat sosial ekonomi orang tua si anak.

Metode yang digunakan Hakim dalam mengambil keputusan tentang pemeliharaan Hak Asuh Anak di Mahkamah Syar'iyah dalam Putusan Perkara No.150/Pdt.G/2015/ Makamah Syar'iyah Langsa adalah dengan menggunakan metode yuridis undang-undang mengamanahkan anak yang masih di bawah umur berada di pengasuhan ibunya, walaupun ibunya sudah menikah lagi, namun jika terdapat hal-hal buruk yang dapat dikatagorikan bisa mempengaruhi hak pengasuhan anak maka itu bisa dikesampingkan dan berdasarkan ketentuan tersebut hak pengasuhan bisa dialihkan.

\section{DAFTAR PUSTAKA}

Abdul Fatah Idris, Abu Ahmadi, Fiqih Islam Lengkap, Jakarta: PT Rineka Cipta, 2004.

Abu Bakar Muhammad al-Sarkhasi, Syamsuddin, al-Mabsuth, jilid 5, Beirut: Dar al-Ma'rifah, t.th.

Ali, Zainuddin, Hukum Perdata Islam Di Indonesia, Jakarta: Sinar Grafika, 2007.

Amir Syarifuddin, Hukum Perkawinan Islam di Indonesia: Antara Fiqh Munakahat dan Undang-Undang Perkawinan, Jakarta: Kencana, 2007.

Az-Zuhaili, Wahbah, Fiqih Islam Wa Adillatuhu, jilid 10, Terj. Abdul Hayyie alKattani dkk., Jakarta: Gema Insani \& Darul Fikir, 2011.

Fatah, Idris dan Abu Ahmadi, Abdul, Fikih Islam Lengkap, Jakarta: Rineka Cipta, 2004.

Hasan Ayyub, Syaikh, Fiqh Keluarga, Jakarta: Pustaka Al-Kautsar, 2004. 
AL-QADHA Jurnal Hukum Islam Dan Perundang-undangan

Malik bin Anas Al-Ashbahi, Al-Mudawwanah Al-Kubra, jilid 2, Beirut: Darul Kutub Al-Ilmiyah, 1994.

Manan, Abdul, Penerapan Hukum Acara Perdata Di Lingkungan Peradilan Agama, Jakarta: Kencana, 2008.

Mubarok, Jaiz , Peradilan Agama Di Indonesia, Bandung: Pustaka Bani Quraisy, 2004.

Muhammad Bin Idris Asy-Syafi'i, Al-Umm, jilid 7, Beirut: Dar Al-Ma'rifah, t.th.

Qudamah, Ibnu, Al-Mughni, jilid 8, Riyadz: Dar 'Alamal Kutub, t.th .

Sabiq, Sayyid, Fiqh Sunnah, jilid 2, Beirut: Dar Fikr,1983.

Satria Effendi M. Zein, Problematika Hukum Keluarga Islam Kontemporer..., hlm. 181.

Slamet Abidin, Fiqh Munakahat, Bandung : Pustaka Setia, 1999.

Tahido Yanggo, Huzaemah, Fikih Perempuan Kontemporer, Jakarta: Ghalia Indonesia, 2010.

Tihami dan Sohari Sahrani, Fikih Munakahat: Kajian Fikih Nikah Lengkap, Jakarta: Rajagrafindo Persada.

Zulkarnain Nasution, Ahmad Dayan Lubis, dll, Kompilasi Peraturan PerundangUndangan tentang Narkoba, (Pimansu).

Wawancara Dengan Hakim Bapak Salamat Nasution, Hakim Mahkamah Syar'iyah Langsa. 